\title{
Power-to-X in Denmark: An Analysis of Strengths, Weaknesses, Opportunities and Threats
}

\author{
Iva Ridjan Skov ${ }^{1, *}$, Noémi Schneider ${ }^{1}$, Gerald Schweiger ${ }^{2}$, Josef-Peter Schöggl ${ }^{3,4}\left(\mathbb{D}\right.$ and Alfred Posch ${ }^{5}(\mathbb{C}$ \\ 1 Department of Planning, Aalborg University, 2450 Copenhagen, Denmark; noemi@plan.aau.dk \\ 2 Institute of Software Technology, Graz University of Technology, 8010 Graz, Austria; \\ gerald.schweiger@tugraz.at \\ 3 Christian Doppler Laboratory for Sustainable Product Management, University of Graz, 8010 Graz, Austria; \\ josef.schoeggl@uni-graz.at \\ 4 Center for ECO2 Vehicle Design, KTH Royal Institute of Technology, SE-100 44 Stockholm, Sweden \\ 5 Institute of Systems Sciences, Innovation and Sustainability Research, University of Graz, 8010 Graz, Austria; \\ alfred.posch@uni-graz.at \\ * Correspondence: iva@plan.aau.dk
}

Citation: Skov, I.R.; Schneider, N.; Schweiger, G.; Schöggl, J.-P.; Posch, A. Power-to-X in Denmark: An Analysis of Strengths, Weaknesses,

Opportunities and Threats. Energies 2021, 14, 913. https://doi.org/ 10.3390/en14040913

Academic Editor: Jinliang Yuan

Received: 18 January 2021

Accepted: 2 February 2021

Published: 9 February 2021

Publisher's Note: MDPI stays neutral with regard to jurisdictional claims in published maps and institutional affiliations.

Copyright: (c) 2021 by the authors. Licensee MDPI, Basel, Switzerland. This article is an open access article distributed under the terms and conditions of the Creative Commons Attribution (CC BY) license (https:// creativecommons.org/licenses/by/ $4.0 /)$.

\begin{abstract}
Power-to- $X$ is an upcoming sector-coupling technology that can play a role in the decarbonisation of energy systems. The aim of this study was to widen the current knowledge of strengths, weaknesses, opportunities, and threats (SWOT) of this innovative technology in the Danish context by utilizing the analytic hierarchy process (AHP) to evaluate and compare perception of academic and industrial experts. The results of this analysis indicate that the external factors such as current policy framework are more important than the internal technology related factors. Further, positive factors predominate negative ones, with academic experts indicating strengths as the most important category and practitioners' opportunities. All experts consider the country being a P2X knowledge hub as one of the most important factors, and in the given context of the Danish energy system, wind developments and Danish industrial environment, seizing this opportunity could be the biggest enabler for P2X success.
\end{abstract}

Keywords: Power-to-X; SWOT-AHP; P2X; electrofuel

\section{Introduction}

The combustion of fossil fuels is the main anthropogenic driver of climate change [1]. The energy sector emits $78 \%$ of the total greenhouse gas (GHG) emissions of the EU according to Kyoto Protocol in 2018 [2]. The transition to renewable energy is a central strategy to mitigate climate change. In the EU plus Iceland, $17.5 \%$ of the consumed energy in 2017 stems from renewable sources, whereas the electricity sector has a share of $31 \%$, the heating and cooling sector of $19.5 \%$, and the transport sector of $7.6 \%$ renewable energy [3]. However, transition to renewable energy needs to be supported with other measures, otherwise, the transition to $100 \%$ renewable energy system cannot be achieved. To reduce GHG emissions from the energy sector, (i) the energy demand must be reduced, (ii) efficiency for generating and distributing of energy improved, (iii) end use electrified, and (iv) the share of renewable energy substantially increased $[4,5]$.

In the current, fossil fuel based energy system, the flexibility to meet the demand lies within (the storage of) the resources. Fluctuating renewable energy sources, however, cannot provide this flexibility. The smart energy system introduced by Lund et al. [6], therefore, takes a holistic energy system approach for a 100\% renewable energy system. By coupling the electricity, heating and transport sector and utilizing energy storage, the lost flexibility can be generated in the energy system [7]. Power-to-X (P2X) is a key element of sector coupling. Most commonly, P2X stands for power-to-fuels or chemicals, where electricity production is typically via electrolysis converted to different types of endproducts such as hydrogen, synthetic gases, hydrocarbons or chemicals [8]. In this study, 
P2X stands for all technological pathways combining electrolysis technologies (alkaline, polymer electrolyte membrane, and solid-oxide-high temperature), with carbon source in the form of gasification of biomass or other means of production of biogas or $\mathrm{CO}_{2}$ capture, nitrogen source, and finally its conversion to methanol, methane or ammonia. Methanol and methane can be further processed to other liquid fuels if desired.

Even though some of the technologies in the P2X value chain have been known for 100 years, the concept of production of electrofuels is relatively new [9]. However, activities have progressed at a considerably faster rate than had been predicted just a couple of years ago, with a total of 220 P2X research and demonstration projects in Europe either been realized, completed, or currently being planned as of June 2020 [10]. Nevertheless, technical aspects, like the utilization of intermittent renewable resources and the degradation processes [11], as well as non-technical aspects, like regulatory frameworks [12], lack of market formation [13], social acceptance, current prices and lack of comprehensive life-cycle assessment (LCA), challenge the introduction of P2X [14]

Figure 1 illustrates a keyword analysis on Scopus, showing a significant increase of publications about the topic "Power-to- $X$ " in recent years, indicating that this concept is indeed discussed in the scientific literature. However, there still exists a knowledge gap concerning SWOT factors, as none of the publications included in the review have looked into this specific topic.

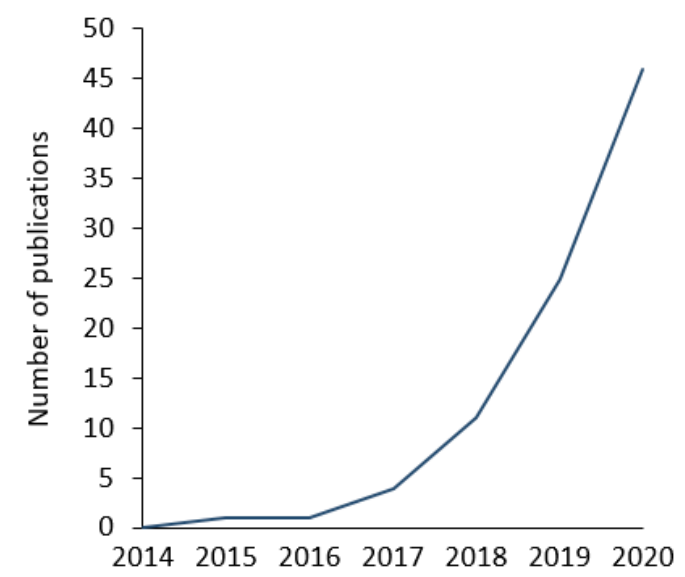

Figure 1. Number of publications between 2014 and October 2020 that include the term Power-to-X in the title, abstract, or keywords according to the literature database Scopus. Excluding not relevant publications as P2X term stands also for P2X7 and paclitaxel.

This paper fills in the gap by investigating the technology-inherent strengths and weaknesses, and external opportunities and threats (SWOT) of P2X technologies in the Danish context. By pairing SWOT analysis with the multicriteria decision-making technique called Analytic Hierarchy Process (AHP), the paper evaluates and equates the perception of academic experts and experts from the field about P2X technologies. Denmark was chosen as it already has high shares of renewable energy and ambitious targets for 2030 with $70 \%$ reductions in $\mathrm{CO}_{2}$ emissions and 2050 targets to be fossil free [15], as well as relevant actors that can drive the technology implementation.

\section{Methods}

To analyse the strengths, weaknesses, opportunities, and threats of P2X in Denmark, a two-stage expert survey was conducted, relying on four main expert groups: (i) academia, (ii) public authorities, (iii) energy providers/network operators, and (iv) technology producers. We selected the individual experts from academia (i) based on their number of publications on P2X or related topics that are listed in the literature database Scopus [16]. The Danish practitioners (ii-iv) were chosen according to their actual involvement or keen interest in $\mathrm{P} 2 \mathrm{X}$ projects. 
In the first empirical round, we invited eleven persons to qualitative interviews, of which all agreed (see Table 1). The interviews took place in March and April 2020, with the aim of establishing a list of the main SWOT-factors. The interview guidelines (i) included a description of the P2X technology to avoid contributions outside the scope of the study, and (ii) on open questions to avoid possible biased answers and to avoid missing important issues and perspectives. We transcribed the interviews by using Otter [17] and conducted a qualitative content analysis of the answers to identify the commonly mentioned SWOTfactors [18]. The analysis ended in a list of four factors for each of the SWOT categories as a result of merging and grouping the answers from the experts. The findings from the first round of expert interviews represent relevant technology-inherent strengths and weaknesses, and technology-external opportunities and threats of P2X in Denmark.

Table 1. Composition of the samples of the first and second phases of the empirical survey.

\begin{tabular}{|c|c|c|c|c|c|c|}
\hline \multirow[t]{2}{*}{ Approach } & \multirow{2}{*}{$\begin{array}{l}\text { Research } \\
\text { Academic } \\
\text { experts }\end{array}$} & \multicolumn{4}{|c|}{ Practitioner } & \multirow[b]{2}{*}{ Total } \\
\hline & & $\begin{array}{c}\text { Public } \\
\text { authorities }\end{array}$ & $\begin{array}{c}\text { Energy } \\
\text { providers / } \\
\text { Network } \\
\text { operators }\end{array}$ & $\begin{array}{l}\text { Technology } \\
\text { producers }\end{array}$ & Other * & \\
\hline $\begin{array}{c}\text { SWOT Phase } 1 \\
\text { qualitative }\end{array}$ & 3 & 1 & 4 & 3 & & 11 \\
\hline $\begin{array}{c}\text { SWOT Phase } 2 \\
\text { semi- } \\
\text { quantitative }\end{array}$ & 11 & 1 & 2 & 4 & 10 & 28 \\
\hline
\end{tabular}

In a second round, experts were asked to judge the relative importance of the SWOT factors identified in the first round. For doing so, the Analytic Hierarchy Process (AHP) method according to Saaty [19] was used. The AHP has been used previously in a number of studies focused on sustainable development in general, [20], and renewable energy technologies in particular [21]. In the paper at hand, we integrate the AHP with a SWOT analysis to assess the SWOT factors' relative priorities. Sixty-seven experts were invited to the second survey round (online via LimeSurvey), of which 28 completed it. As illustrated in Table 1, eleven experts were from academia and 17 from practice, resulting in a response rate of $41.8 \%$.

The survey consisted of a pairwise comparison of the predefined SWOT factors, i.e., for each factor pair, the experts had to rate which factor is how much more important than the other. Given the four factors per group, six comparisons were conducted by SWOT group. Randomizing the order of the comparisons prevented a systematic bias in the experts' answers. To validate the predefined SWOT factors' selection, the experts were asked to provide any other factor they would consider more important than the ones listed. This question was asked for each SWOT group, but the respondents brought up no other essential factors. In addition to comparing the individual SWOT factors per group, the experts had to also compare the groups amongst each other to derive group priorities.

For all the comparisons, we applied the nine-step scale proposed by Saaty [22]. The scale ranges from 9 (meaning that factor " $a$ " is much more important than factor " $b$ "), over 1 (meaning equal importance of factors " $a$ " and " $b$ ") to $1 / 9$ (meaning that factor " $b$ " is much more important than factor "a"). We omitted the even numbers as intermediate steps. Each pairwise comparison followed the logic explained above for the comparison of factor "a" and "b".

The individual judgements of the participants were furthermore aggregated using the geometric mean method [23]. The aggregated judgements and their reciprocal counterparts were furthermore used to fill five matrices. These matrices corresponded to the four categories "Strengths", "Weaknesses", "Opportunities", and "Threats", as well as to the comparison among them. The relative factor priorities (i.e., local priorities) and the group priorities were calculated using the eigenvalue method in line with Saaty [19]. For each of 
the five matrices, the consistency ratios where calculated according to Saaty [19]. Finally, by weighing the individual factor priorities with the respective group priorities, a normalized global priority was obtained for each factor. For conducting the AHP, we used R version 4.0.2 [24] and the package "ahpsurvey" version 0.4.1 [25].

Moreover, additional qualitative statements on potential niche markets as well as on regulatory framework and incentive structures were included in the second part of the survey. Experts were asked to assess their level of agreement with 24 statements on a seven-level Likert scale. The possible levels at the scale were (1) Entirely disagree, (2) Mostly disagree, (3) Somewhat disagree, (4) Neither agree nor disagree, (5) Somewhat agree, (6) Mostly agree, (7) Entirely agree.

\section{Results and Discussion}

\subsection{Identified SWOT-Factors}

The outcome of the interviews conducted with academic and industrial experts were 16 SWOT-factors, i.e., four factors in each category, which are presented in Table 2 and described below. The strengths and weaknesses of Power-to-X are positive and negative factors that are technology-inherent, while the opportunities and threats are positive and negative factors or potential developments in the surrounding system in which the technology is embedded. All identified SWOT-factors are supposed to influence the further diffusion, i.e., the success of the technology in the given context of the Danish energy system. In the following, these factors are briefly described and brought into relation to existing scientific literature on Power-to-X.

Table 2. Overview of the main SWOT factors regarding Power-to- $X$ in Denmark based on the first round of expert interviews.

\begin{tabular}{|c|c|c|}
\hline & Positive & Negative \\
\hline \multirow{5}{*}{ Internal } & Strengths & Weaknesses \\
\hline & Sa: P2X improves system flexibility & $\begin{array}{l}\text { Wa: P2X lacks cost competitiveness due to } \\
\text { electricity price and electrolysis CAPEX }\end{array}$ \\
\hline & Sb: P2X enables sector coupling & $\begin{array}{l}\mathrm{Wb}: \text { P2X lacks upscaling and manufacturing } \\
\text { production capacity }\end{array}$ \\
\hline & $\begin{array}{c}\text { Sc: P2X provides a large spectrum of end-products } \\
\text { that are compatible with existing infrastructure } \\
\text { and equipment }\end{array}$ & $\begin{array}{l}\text { Wc: P2X technologies have low } \\
\text { production efficiency }\end{array}$ \\
\hline & $\begin{array}{c}\text { Sd: P2X contributes to decarbonize parts of } \\
\text { transport sector not suitable for direct } \\
\text { electrification }\end{array}$ & $\begin{array}{c}\text { Wd: P2X technologies are immature and have } \\
\text { short lifetime (electrolysis) }\end{array}$ \\
\hline \multirow{5}{*}{ External } & Opportunities & Threats \\
\hline & $\begin{array}{l}\text { Oa: The European Union ambitious climate targets } \\
\text { support further expansion of renewable energy. }\end{array}$ & $\begin{array}{l}\text { Ta: Competitive technologies are more visible and } \\
\text { economically attractive }\end{array}$ \\
\hline & $\begin{array}{l}\text { Ob: Consensus on limited biomass availability and } \\
\text { the need to minimise its use }\end{array}$ & $\begin{array}{l}\text { Tb: Uncertainty upon fuel market readiness or } \\
\text { support schemes. }\end{array}$ \\
\hline & $\begin{array}{l}\text { Oc: Existing district heating networks can benefit } \\
\text { from excess heat from the P2X processes. }\end{array}$ & Tc: Rising electricity prices \\
\hline & Od: Denmark is a P2X knowledge hub. & $\begin{array}{l}\text { Td: Uncertainty on the climate agenda due to } \\
\text { external shocks such as the COVID- } 19 \text { pandemic }\end{array}$ \\
\hline
\end{tabular}

As strengths of Power-to- $X$, the experts indicated the improved flexibility of the energy system (Sa), directly linked to this, the enabled sector coupling $(\mathrm{Sb})$, the large spectrum of end-products (Sc), and the potential contribution to the decarbonization of parts of the transport sector that are not suitable for direct electrification (Sd). The high emphasis on the benefits of P2X as a technology that improves the system flexibility $(\mathrm{Sa})[7,26-28]$ needs to be seen in the context of the already high level of electricity production from 
fluctuating renewable energy sources such as wind power and PV in Denmark. At this stage, the system flexibility becomes a critical factor in the energy transition by allowing for higher penetration of renewables [29]. A further key feature of P2X, as indicated by its name, was seen in the technology's potential to enable to connection of the power sector to other energy sectors, such as to the heating or transport sector (Sb) [30-32]. The experts also stated that a strength lies in the large spectrum of end-products, i.e., energy carriers (different possible " $X$ "), which can be produced by this technology (Sc). This is important especially in regard to the compatibility with existing infrastructure and equipment: gas networks and storage facilities, industrial processes, vehicles with internal combustion engines, etc. [33]. Finally, with hydrogen or electrofuels generated with electricity and carbon (or nitrogen) source from renewables, P2X offers a solution to the decarbonisation of parts of the transport sector that are not suitable for direct electrification (Sd), such as heavy duty road transport (mainly long-haul), aviation and shipping [31,34,35]. The contribution of P2X has also been recognized as a potential part of meeting the Danish $70 \%$ $\mathrm{CO}_{2}$ reductions goal in 2030 [36,37].

The weaknesses of P2X that were named by the experts refer to low competitiveness of the technology $(\mathrm{Wa})$, the lack in production capacity $(\mathrm{Wb})$, low production efficiency $(\mathrm{Wc})$, and the immaturity and short lifetime of the electrolysis (Wd). As a consequence of the high investment cost of electrolysers and the higher price of electricity compared to other energy carriers such as gas, P2X currently lacks cost efficiency compared to other hydrogen production processes (Wa) [38-40]. Furthermore, production capacities of electrolysis cells and stacks are not sufficient at present in Denmark to allow upscaling $(\mathrm{Wb})[41,42]$. In addition, P2X is a power-intensive technology, which leads to low energy efficiency with currently available technologies (Wc) [43]. As another disadvantage, even if some electrolysis technologies such as alkaline have a high Technology Readiness Level (TRL), lifetime of electrolysis units might be relatively short and, when it comes to linking to electrofuel production, most of the technologies have not been demonstrated on larger scale and can be defined as immature (Wd) $[41,42,44]$.

As opportunities, i.e., external positive factors, the experts identified factors related to ambitious EU climate targets (Oa), the consensus on the limited availability of biomass and the resulting need to lower its use $(\mathrm{Ob})$, the existing district heating networks in Denmark that can benefit from the technology (Oc), and the fact that Denmark is perceived as P2X knowledge hub (Od). The higher the production of electricity from variable renewable energy sources, the more the development of P2X will be favoured [45]. In this respect, the ambitious climate policies of the European Union and Denmark, which set targets for renewable energy production, represent an actual opportunity for P2X $(\mathrm{Oa})[15,46]$. There is also nowadays a consensus on the limited availability of (sustainable) biomass [47]. Yet precisely, P2X either uses bioenergy in the most efficient way [48], or can be decoupled from bioenergy with direct carbon [49] or nitrogen capture from the air. The consensus on the need for minimising the use of biomass thus constitutes an opportunity for P2X technologies $(\mathrm{Ob})$. Another opportunity for P2X in Denmark is that the production process produces excess heat, which could be sold to the many existing district heating networks (Oc) [50]. Finally, Denmark's leadership in the fight against climate change has for many years encouraged the involvement of academia and industry in finding sustainable alternatives to fossil fuels, including in challenging key sectors such as heavy transport. In conjunction with Denmark's abundant offshore wind resources and diverse supply chains within sustainable solutions, this creates the potential to make Denmark a knowledge hub for the development of P2X solutions (Od). Denmark has all predispositions to establish the strong position within the P2X market, acting as a knowledge and product exporter, by having local producers of wind turbines, electrolysers, and fuel synthesis.

Threats to the P2X technology are seen in competitive technologies that are more visible and economically attractive (Ta), the uncertainty upon fuel market readiness or support schemes $(\mathrm{Tb})$, rising electricity prices $(\mathrm{Tc})$, and finally the uncertainty on the climate agenda due to external shocks such as the COVID 19 pandemic (Td). P2X has to face the 
competition with other more visible and economically attractive technologies $(\mathrm{Ta})$ that could supersede it to deliver on the climate targets, such as biofuels, or blue hydrogen and carbon capture and storage [51]. Another threat is seen in the uncertainty in the fuel market readiness or support schemes $(\mathrm{Tb})$. In fact, the market framework is not adapted to facilitate the use of electrofuels [41], for which there is currently no certification schemes, and wellestablished lobbies keep securing support schemes for competing technologies. Moreover, as some experts mentioned as a weakness, P2X technologies efficiency is still rather low and needs large electricity inputs in order to produce fuels. Therefore, if the electricity price from renewables is not low or there is a need for purchasing electricity from the grid with belonging tariffs, there is a risk that P2X cannot become a cost competitive option (Tc) [35], which would be exacerbated if no support scheme is implemented [52]. Denmark however, could potentially, due to the low prices of renewable electricity production produce P2Xproducts at lower costs than other parts of Europe. In addition, there is always a risk that the climate agenda will be called into question by economic shocks such as that generated by the COVID-19 crisis (Td), sweeping away the opportunities for the development of P2X not only in Denmark but worldwide.

\subsection{Relative Importance of SWOT-Factors}

As a next step, the relative relevance of these SWOT-factors, which were derived from expert interviews and backed-up with scientific literature, was investigated by conducting an AHP-analysis based on the results of an online survey (as presented in the Methods section). The results were separately analysed for academic experts and practitioners and presented in table format (Tables 3 and 4 ) and graphically (Figures 2 and 3). As illustrated in Table 3, all comparison matrices exhibit consistency ratios below the threshold of 0.1, which suggests an acceptable amount of inconsistencies [22].

Table 3. Consistency ratios.

\begin{tabular}{cccccc}
\hline & Strengths & Weaknesses & Opportunities & Threats & Groups \\
\hline Academics & 0.05 & 0.04 & 0.01 & 0.03 & 0.00 \\
Practitioners & 0.02 & 0.00 & 0.01 & 0.00 & 0.02 \\
\hline
\end{tabular}

Table 4. Priority scores given to different SWOT factors and categories by academics and practitioners.

\begin{tabular}{|c|c|c|c|c|}
\hline & \multicolumn{2}{|c|}{ Factor Priority } & \multicolumn{2}{|c|}{ Overall Priority } \\
\hline & Academics & Practitioners & Academics & Practitioners \\
\hline Strengths & & & 0.41 & 0.26 \\
\hline Sa: P2X improves system flexibility & 0.09 & 0.14 & 0.04 & 0.04 \\
\hline Sb: P2X enables sector coupling & 0.15 & 0.25 & 0.06 & 0.07 \\
\hline $\begin{array}{l}\text { Sc: P2X provides a large spectrum of end-products that are } \\
\text { compatible with existing infrastructure and equipment }\end{array}$ & 0.17 & 0.26 & 0.07 & 0.07 \\
\hline $\begin{array}{l}\text { Sd: P2X contributes to decarbonize parts of transport sector not } \\
\text { suitable for direct electrification }\end{array}$ & 0.60 & 0.35 & 0.24 & 0.09 \\
\hline Weaknesses & & & 0.09 & 0.20 \\
\hline $\begin{array}{c}\text { Wa: P2X lacks cost competitiveness due to electricity price and } \\
\text { electrolysis CAPEX }\end{array}$ & 0.23 & 0.45 & 0.02 & 0.09 \\
\hline Wb: P2X lacks upscaling and manufacturing production capacity & 0.34 & 0.27 & 0.03 & 0.05 \\
\hline Wc: P2X technologies have low production efficiency & 0.10 & 0.14 & 0.01 & 0.03 \\
\hline $\begin{array}{c}\text { Wd: P2X technologies are immature and have short lifetime } \\
\text { (electrolysis) }\end{array}$ & 0.33 & 0.14 & 0.03 & 0.03 \\
\hline
\end{tabular}


Table 4. Cont.

\begin{tabular}{|c|c|c|c|c|}
\hline & \multicolumn{2}{|c|}{ Factor Priority } & \multicolumn{2}{|c|}{ Overall Priority } \\
\hline & Academics & Practitioners & Academics & Practitioners \\
\hline Opportunities & & & 0.39 & 0.35 \\
\hline $\begin{array}{l}\text { Oa: The European Union's ambitious climate targets support for } \\
\text { further expansion of renewable energy. }\end{array}$ & 0.23 & 0.29 & 0.09 & 0.10 \\
\hline $\begin{array}{l}\text { Ob: Consensus on limited biomass availability and the need to } \\
\text { minimise its use }\end{array}$ & 0.32 & 0.18 & 0.12 & 0.06 \\
\hline $\begin{array}{l}\text { Oc: Existing district heating networks can benefit from excess heat } \\
\text { from the P2X processes. }\end{array}$ & 0.15 & 0.20 & 0.06 & 0.07 \\
\hline Od: Denmark is a P2X knowledge hub. & 0.31 & 0.33 & 0.12 & 0.12 \\
\hline Threats & & & 0.11 & 0.18 \\
\hline $\begin{array}{l}\text { Ta: Competitive technologies are more visible and economically } \\
\text { attractive }\end{array}$ & 0.23 & 0.18 & 0.03 & 0.03 \\
\hline Tb: Uncertainty upon fuel market readiness or support schemes. & 0.41 & 0.53 & 0.05 & 0.09 \\
\hline Tc: Rising electricity prices & 0.20 & 0.15 & 0.02 & 0.03 \\
\hline $\begin{array}{l}\text { Td: Uncertainty on the climate agenda due to external shocks such } \\
\text { as the COVID } 19 \text { pandemic }\end{array}$ & 0.16 & 0.14 & 0.02 & 0.03 \\
\hline
\end{tabular}

Bold values indicate the highest priority scores for each factor and category.

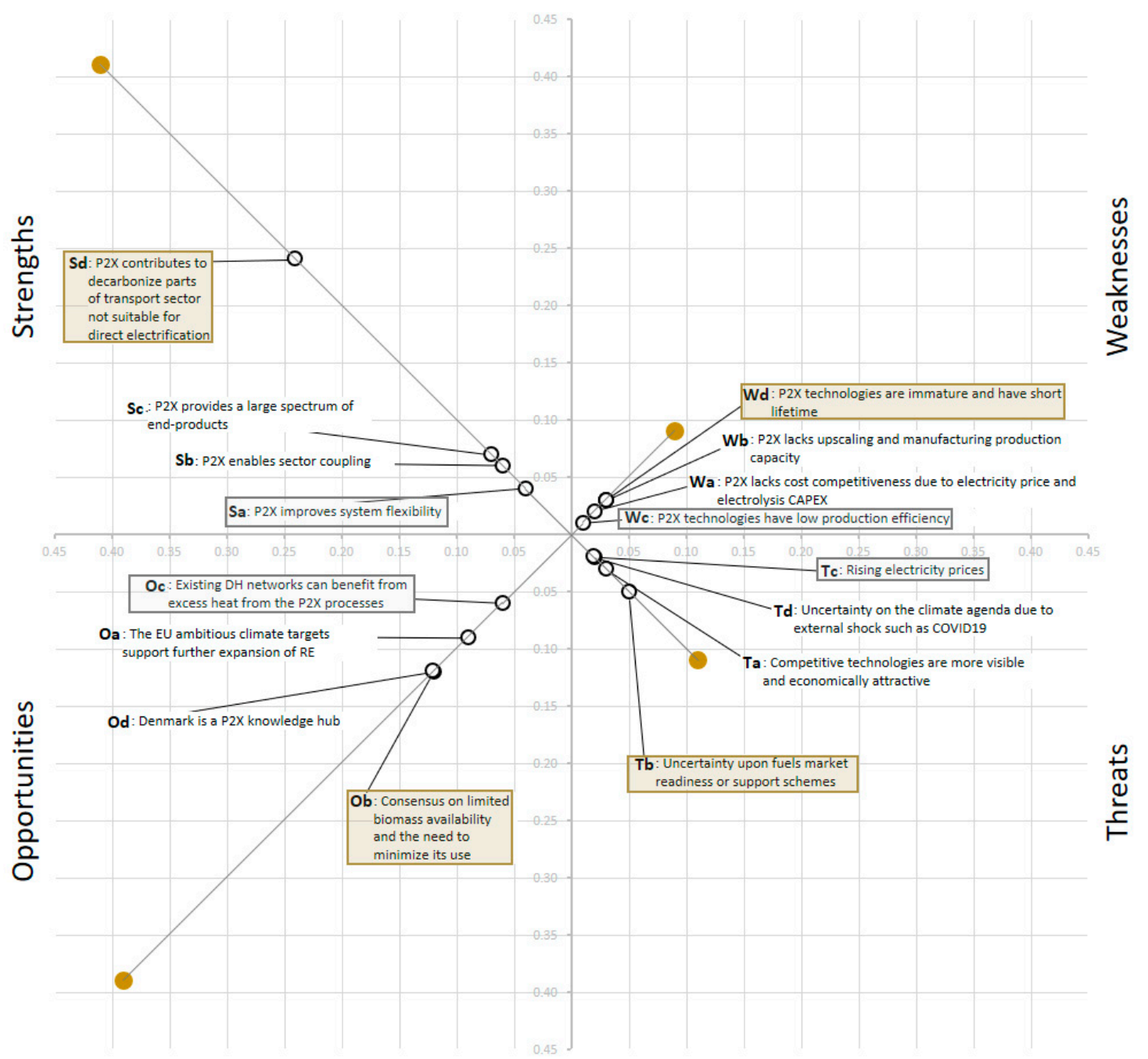

Figure 2. Illustration of integrated SWOT-AHP analysis results as perceived by academic experts. The highest importance is highlighted in yellow; the lowest importance in grey. 


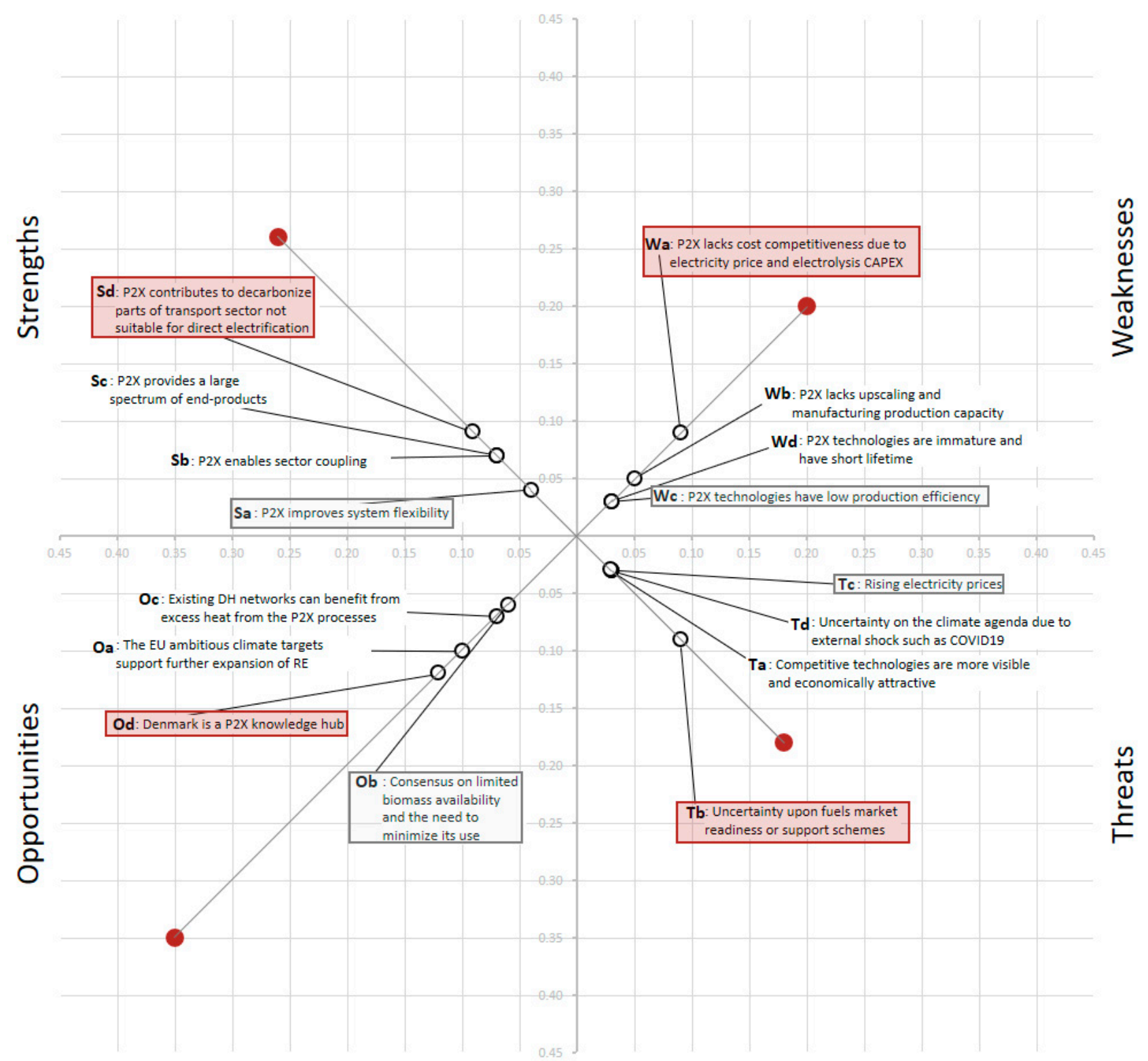

Figure 3. Illustration of integrated SWOT-AHP analysis results as perceived by practitioners. The highest importance in the field is marked in red, the lowest importance in grey.

Graphical illustration of the results is visible below; Figure 2 shows the results for the academic experts and Figure 3 for the practitioners. The four sections of the graph illustrate the four SWOT fields, with the length of the diagonally running straight line, starting from the origin $(0 ; 0)$ to the yellow or red filled point, representing the relative importance of the respective SWOT field. Each of the four factors identified per SWOT field is illustrated by a transparent circle, whereas the distance between the circle and the origin represents the overall priority of the respective factor. The longer the distance from the origin, the higher the importance of the factors and the SWOT field.

The different priority scores $(p)$ given to individual SWOT factors by the two expert groups point out to main dissimilarities in the perceived importance of those SWOT factors. In the academic group, the Strength category received the highest overall score $(p=0.41)$, followed by Opportunities $(p=0.39)$, while Threats $(p=0.11)$ and Weaknesses $(p=0.09)$ were perceived far less important. In contrast, in the practitioner's group, Opportunities $(p=0.35)$ received the highest overall scores, followed by Strengths $(p=0.26)$; 
again Threats $(p=0.18)$ and Weaknesses $(p=0.20)$ seen as less important. This means that academics who do research on P2X are optimistic about the technology mainly because of its inherent strengths, while practitioners are optimistic because of the positive developments in the context of the technology. However, the analysis of the survey results shows that the combined positive values of academic and practitioner groups were 0.32 and 0.37 , respectively, and combined negative values were 0.15 and 0.15 , pointing that the positive factors clearly dominate the negative factors.

The overall priority score indicate that academic experts identified the strength " $P 2 X$ contributes to decarbonize parts of transport sector not suitable for direct electrification" as the most important factor of all 16 factors, while the practitioners consider that "Denmark is a P2X knowledge hub" as the most important. Both academic experts and practitioners had this factor in their top three priority scores. Even though Denmark has been lagging behind Germany in the deployment of P2X technologies [53,54], Denmark being a wind knowledge hub and a country that has strong industrial actors and producers of P2X technology represents a big opportunity for the deployment of this technology [55]. Even though there is no commercial production of P2X products in Denmark to this date, there is an ambition to commercialize this technology in the near future. As a part of project Green fuels for Denmark, the biggest electricity provider Ørsted engages in establishing the world's first energy island with a P2X fuel factory at the Danish island of Brønholm [56]. Further, Ørsted is demonstrating a large-scale electrolysis plant for hydrogen production close to Copenhagen as a part of the H2RES project [57]. The Danish government has granted two other large-scale Power-to-X projects: HySynergy and Greenlab Skive Powerto- $X$, the first project with the aim to green the fossil fuel based production of hydrogen in a large-scale facility at a Shell refinery, and the latter to establish a commercial production facility of hydrogen with part processing of methanol for heavy-duty transport [58].

Within the Strength and Threats categories, the ranking of the factors by academics and practitioners was very similar, while the Opportunities and Weaknesses categories indicate disagreements between academic experts and practitioners. Both groups agree that the potential contribution of the P2X technology to decarbonize those parts of the transportation sector that cannot be electrified (Sd) is the key strength that could be leveraged for this technology and its deployment. Here, the "Uncertainty upon fuel market readiness or support schemes" is considered as the most important threat for the future of the P2X. However, it has been ranked as the third highest overall priority by practitioners but is not so highly ranked by academics. This difference could be explained by the fact that practitioners are aware that they will have to produce and implement the products on the market, but business cases of P2X projects seems at the moment very dependent on the support schemes. The uncertainty regarding support schemes has been discussed in the literature before [41], pointing to lack of clarity on how P2X fuels should be accounted for in meeting the renewable energy targets, especially for the fuels originating from carbon emissions. RED II directive [59] seems also to pose the limitations of connecting the P2X production units to the existing renewable infrastructure to avoid double support schemes.

There is a disagreement between the two expert groups on the importance of the factor "Consensus on limited biomass availability and the need to minimise its use". While academic experts have ranked this factor with the second highest priority overall, practitioners ranked it very low, even as the least relevant factor in the Opportunities field, with an overall priority rank of nine. In this regard, it needs to be stated that the P2X technology can definitely offer a range of fuel derivatives that are independent of biomass sources or minimize the use of it in the production process. Certainly, the biomass potential is often difficult to compare across studies [60]; however, there are regions in the EU that are richer in biomass resources than others, Denmark being one of them. This could be an explanation of the different ranking. Practitioners ranked the factor that "The European Union ambitious climate targets support further expansion of renewable energy" [59] with second highest overall priority. The climate targets for increasing the share of renewable energy are a 
very important opportunity for the deployment of P2X technologies in the system, as they enable integration of RES by improving the system flexibility (Sa) with sector coupling (Sb).

While academics point that the "immaturity and the short lifetime of the P2X technologies" as the most important weakness factor, practitioners point towards "lack of P2X competitiveness". P2X has been struggling to enter the market, due to high prices in comparison to fossil-based products. Further, it has for a long time been compared with other technologies that do not necessarily represent a competition, such as energy storage systems or electric vehicles. Low carbon prices arguably spur investment in long-term abatement technologies such as P2X, and potential changes to the EU-ETS [61] or imposed carbon taxes could lead to higher competitiveness of this technology.

\subsection{Additional Quantitative Results}

In the second part of the survey, experts were provided different statements on potential niche markets as well as on regulatory framework and incentive structures, and asked the question: "To what extent do you agree to the following statements?" The possible answers ranged from "Entirely agree" (7) to "Entirely disagree" (1) on a sevenpoint Likert scale. Table 5 shows the mean, median, and interpolated median of the answers for the respective questions.

Table 5. Statistical analysis of the answers from both academics and practitioners.

\begin{tabular}{|c|c|c|c|}
\hline $\begin{array}{c}\text { Statements on Potential Niche Markets, Regulatory Framework and } \\
\text { Incentive Structures of P2X }\end{array}$ & Mean & Median & Interp. Median \\
\hline There is currently enough public funding for $\mathrm{P} 2 \mathrm{X}$ & 3.3 & 2.0 & 2.2 \\
\hline Ammonia combustion engines are solution for lorries. trucks and tractors & 4.1 & 4.0 & 3.7 \\
\hline $\begin{array}{c}\text { Blending options for P2X fuels (such as methanol and DME) have been } \\
\text { sufficiently } \\
\text { investigated }\end{array}$ & 4.3 & 4.0 & 3.8 \\
\hline $\begin{array}{l}\text { Hydrogen bus fleets are an essential stepping stone to push the development } \\
\text { of P2X further }\end{array}$ & 4.4 & 5.0 & 4.7 \\
\hline Methanol fuel cell cars are a potential niche market & 5.0 & 5.0 & 4.8 \\
\hline $\begin{array}{c}\begin{array}{c}\text { Small decentralised ammonia production for agricultural industry is an } \\
\text { attractive } \\
\text { niche market }\end{array}\end{array}$ & 5.3 & 5.0 & 4.9 \\
\hline $\mathrm{CO}_{2}$ price of $150 € / \mathrm{t}$ is sufficient to enable $\mathrm{P} 2 \mathrm{X}$ implementation & 6.0 & 6.0 & 5.4 \\
\hline Methanol is attractive for the shipping sector & 5.5 & 6.0 & 5.6 \\
\hline Mandatory blending is needed to create competitiveness on the fuel market & 5.6 & 6.0 & 5.7 \\
\hline Green hydrogen is attractive for industrial processes in the existing industry & 5.5 & 6.0 & 5.7 \\
\hline $\mathrm{CO}_{2}$ taxation is needed to enable P2X implementation & 6.0 & 6.0 & 5.9 \\
\hline E-methanol is attractive for chemical industry & 5.7 & 6.0 & 6.0 \\
\hline Ammonia is attractive for the shipping sector & 6.0 & 6.0 & 6.0 \\
\hline P2X fuel certification needs to be further investigated & 6.1 & 6.0 & 6.0 \\
\hline Support schemes for consumers of e-fuels are required & 6.3 & 6.0 & 6.0 \\
\hline $\mathrm{P} 2 \mathrm{X}$ should be prioritized in the chemical and pharmaceutical industry & 6.0 & 6.0 & 6.1 \\
\hline $\begin{array}{c}\text { High purity CO from electrolysis is an interesting option for industrial } \\
\text { purposes }\end{array}$ & 5.8 & 6.0 & 6.1 \\
\hline Support schemes for P2X producers are required & 6.3 & 6.0 & 6.3 \\
\hline $\begin{array}{l}\text { Replacing black hydrogen with green hydrogen in refineries is a transition } \\
\text { step to P2X fuels }\end{array}$ & 6.2 & 7.0 & 6.5 \\
\hline Support schemes for innovation markets are needed & 5.9 & 7.0 & 6.5 \\
\hline $\begin{array}{l}\text { Support schemes for R\&D and demonstration (flagship) projects are required } \\
\text { Mandatory low-carbon footprints of new projects are needed in order to }\end{array}$ & 6.0 & 6.5 & 6.5 \\
\hline $\begin{array}{l}\text { demonstrate } \\
\text { contribution to } \mathrm{CO}_{2} \text { reductions }\end{array}$ & 6.3 & 7.0 & 6.5 \\
\hline Jet fuels are a target market for electrofuels & 6.0 & 7.0 & 6.7 \\
\hline $\begin{array}{c}\text { P2X fuels need to meet a mandatory low carbon footprint in order to } \\
\text { contribute to } \mathrm{CO}_{2} \\
\text { reductions }\end{array}$ & 6.3 & 7.0 & 6.7 \\
\hline
\end{tabular}


The statement with highest disagreement (interp. median of 2.2) is the one that there is enough public funding opportunities for P2X. This is in line with the fact that the respondents agree that there is a need for further funding and support schemes in order to outset the implementation of this technology, most importantly for innovation markets, but also for P2X producers, and least for consumers of electrofuels. The creation of a robust policy framework is indeed important, as P2X technologies have a power to redraw the geography of energy trade [62], independent on which derivative the $X$ represents. Positive political environment on $\mathrm{P} 2 \mathrm{X}$ is raising momentum in Denmark, it is therefore anticipated that concrete policy framework and strategy for deployment of P2X will be developed soon as a part of the $\mathrm{CO}_{2}$ reduction targets [15] as well as long-term energy transition vision.

The statement with the highest rate of agreement is that P2X fuels need to meet a mandatory low carbon footprint to contribute to reductions of carbon emissions. This is in line with different types of P2X and especially targets the origin of carbon source for carbonbased P2X products. Even in policies, the biogenic origin of carbon for reuse and utilization for fuel production is granted priority, ahead of reuse of carbon emissions from for example cement production plants [59]. Actually currently, it is up to the Member states to decide whether they will account the latter in meeting their renewable goals [59]. This is primarily to ensure carbon reductions from P2X fuels. However, there have been debates that hydrocarbons produced by $\mathrm{P} 2 \mathrm{X}$ are not contributing enough to carbon reduction $[63,64]$. Therefore, it is important to have LCA results for the specific P2X derivative in order to see their impact on carbon emissions and potential reductions in comparison to other alternatives. Koj et al. [65] report the evident lack of LCA methodological specifications for P2X technologies.

Targeting P2X towards specific markets could enable faster deployment. Experts agree that jet fuels seem to be the most promising. Schmidt et al. [66] have reviewed power-to-liquids and their role in the aviation sector, pointing out that $\mathrm{P} 2 \mathrm{X}$ is a viable option for the transformation of the aviation sector. According to the experts, a potential end-use sector is the shipping sector with ammonia, which has been investigated in the literature [67] and also specifically for the Danish case [68]. Another possible application is in the chemical industry to displace fossil-based products.

\section{Conclusions}

This study provides important insights on the perceptions of 28 Danish experts from both research institutions and industry on the strengths, weaknesses, opportunities, and threats of P2X technology. The main findings of the study could supposedly influence the success of P2X technology in the Danish energy system. The results show that positive factors are considered more important than their negative counterparts, with the only difference in the order assigned to them; the academics stress factors from the strengths category as the most important and practitioners' opportunities. Both practitioners and academics have two out of three top-rated factors under opportunities. This confirms that they see the potential developments and current frameworks in the surrounding system, in which technology is to be implemented, is more important than the technology-inherent factors.

Both academics and experts from the industry point to Denmark being a P2X knowledge hub (top three priority score overall) as a driver for this technology, both locally but also as being a knowledge exporter. P2X could be seen as a new industrial success story in Denmark due to the strong industrial environment, wind developments, and already high share of renewable electricity in the energy system. Danish experts agree that the main contribution for P2X technology should be its application in the transport sector, as a solution for the decarbonisation of the aviation and shipping sectors as well as long-haul road transport.

We found consistency in the Strength and Threats category, while the Opportunities and Weaknesses categories point towards some disagreements between academic experts and practitioners. While industrial experts are concerned about the lack of P2X cost competitiveness, in connection with the uncertainty upon fuel market readiness or support 
schemes, academics are pointing towards the lack of the production capacity and current technological development status. Academics see consensus of the limited biomass availability as a main opportunity for P2X (as it can offer reduction or elimination of biomass use for fuel production), while practitioners do not value this factor highly within the SWOT category. Finally, both academic experts and practitioners point towards the need for improving the current regulatory framework in order to enable the faster deployment of this technology. Further research is needed to investigate the implications of the different policy initiatives and strategies on the potential deployment of P2X.

Author Contributions: Conceptualization, I.R.S., G.S., A.P., and N.S.; methodology, A.P., G.S., I.R.S., and N.S.; data curation, N.S., I.R.S., G.S., and J.-P.S.; formal analysis, G.S. and J.-P.S.; writing-original draft preparation, I.R.S. and N.S.; writing—review and editing, all authors; visualization, I.R.S. All authors have read and agreed to the published version of the manuscript.

Funding: The co-authors I.S. and N.S. greatly acknowledge the Energy Technology Development and Demonstration Program (EUDP) that financed the Efficient Power2Gas Combining SOEC and Biomass Gasification (EP2Gas) project (project no. 64017-0011).

Institutional Review Board Statement: Not applicable.

Informed Consent Statement: Not applicable.

Data Availability Statement: The data generated from interviews conducted in this study are publicly available, and can be found here: https://github.com/GersHub/SurveyP2X.

Acknowledgments: The co-author J.S. gratefully acknowledges the financial support of the Austrian Federal Ministry for Digital and Economic Affairs, the National Foundation for Research, Technology and Development, and the Christian Doppler Research Association, as well as thanks the Centre for $\mathrm{ECO}^{2}$ Vehicle Design at KTH, funded by the Swedish Innovation Agency Vinnova. The authors' gratitude is extended to the prospective editor(s) and reviewers that will/have spared time to work towards a successful publication.

Conflicts of Interest: The authors declare no conflict of interest. The funders had no role in the design of the study; in the collection, analyses, or interpretation of data; in the writing of the manuscript, or in the decision to publish the results.

\section{References}

1. Dlugokencky, E.J.; Hall, B.D.; Montzka, S.; Dutton, G.; Mühle, J.; Elkins, J.W. Long-lived greenhouse gases. Spec. Suppl. Bull. Am. Meteorol. Soc. 2019, 100, 48-50.

2. European Environmental Agency. Annual European Union Greenhouse Gas Inventory 1990-2018 and Inventory Report 2020: Submission under the United Nations Framework Convention on Climate Change and the Kyoto Protocol; European Environmental Agency: Luxembourg, Belgium, 2020.

3. European Environmental Agency. Trends and Projections in Europe 2019: Tracking Progress towards Europe's Climate and Energy Targets; European Environmental Agency: Luxembourg, Belgium, 2019.

4. IPCC; Masson-Delmotte, V.; Zhai, P.; Pörtner, H.-O.; Roberts, D.; Skea, J.; Shukla, P.; Pirani, A.; Moufouma-Okia, W.; Péan, C.; et al. Global Warming of $1.5^{\circ} \mathrm{C}$. An IPCC Special Report on the Impacts of Global Warming of $1.5^{\circ} \mathrm{C}$ above Pre-Industrial Levels and Related Global Greenhouse Gas Emission Pathways, in the Context of Strengthening the Global Response to the Threat of Climate Change; IPCC: Geneva, Switzerland, 2018.

5. Schweiger, G.; Kuttin, F.; Posch, A. District heating systems: An analysis of strengths, weaknesses, opportunities, and threats of the 4GDH. Energies 2019, 12, 4748. [CrossRef]

6. Lund, H. Renewable Energy Systems: A Smart Energy Systems Approach to the Choice and Modeling of 100\% Renewable Solutions; Academic Press: Burlington, VT, USA, 2014; Volume 2.

7. Mathiesen, B.V.; Lund, H.; Connolly, D.; Wenzel, H.; Østergaard, P.A.; Möller, B.; Nielsen, S.; Ridjan, I.; Karnøe, P.; Sperling, K.; et al. Smart Energy Systems for coherent 100\% renewable energy and transport solutions. Appl. Energy 2015, 145, 139-154. [CrossRef]

8. Foit, S.R.; Vinke, I.C.; de Haart, L.G.J.; Eichel, R.-A. Power-to-Syngas: An Enabling Technology for the Transition of the Energy System? Angew. Chem. Int. Ed. Engl. 2017, 56, 5402-5411. [CrossRef]

9. Holade, Y.; Tuleushova, N.; Tingry, S.; Servat, K.; Napporn, T.W.; Guesmi, H.; Cornu, D.; Kokoh, K.B. Recent advances in the electrooxidation of biomass-based organic molecules for energy, chemicals and hydrogen production. Catal. Sci. Technol. 2020. [CrossRef]

10. Wulf, C.; Zapp, P.; Schreiber, A. Review of Power-to-X Demonstration Projects in Europe. Front. Energy Res. 2020. [CrossRef] 
11. Wang, L.; Zhang, Y.; Pérez-Fortes, M.; Aubin, P.; Lin, T.E.; Yang, Y.; Maréchal, F.; Van herle, J. Reversible solid-oxide cell stack based power-to-x-to-power systems: Comparison of thermodynamic performance. Appl. Energy 2020. [CrossRef]

12. Dolci, F.; Thomas, D.; Hilliard, S.; Guerra, C.F.; Hancke, R.; Ito, H.; Jegoux, M.; Kreeft, G.; Leaver, J.; Newborough, M.; et al. Incentives and legal barriers for power-to-hydrogen pathways: An international snapshot. Int. J. Hydrogen Energy 2019, 44, 11394-11401. [CrossRef]

13. Decourt, B. Weaknesses and drivers for power-to-X diffusion in Europe. Insights from technological innovation system analysis. Int. J. Hydrogen Energy 2019, 44, 17411-17430. [CrossRef]

14. Burre, J.; Bongartz, D.; Brée, L.; Roh, K.; Mitsos, A. Power-to-X: Between Electricity Storage, e-Production, and Demand Side Management. Chemie Ing. Tech. 2020, 92, 74-84. [CrossRef]

15. Danish Ministry of Climate Energy and Utilities. Denmark's Integrated National Energy and Climate Plan, under the Regulation of the European Parliament and the Council on the Gouvernance of the Energy Union and Climate Action; Danish Ministry of Climate Energy and Utilities: Copenhagen, Danmark, 2019.

16. Elsevier Scopus. Available online: https://www.scopus.com/ (accessed on 2 March 2020).

17. Otter Voice Meeting Notes-Otter.ai. Available online: https:/ / otter.ai/login (accessed on 15 April 2020).

18. Mayring, P. Qualitative Content Analysis. In A Companion to Qualitative Research; Sage Publications: Thousand Oaks, CA, USA, 2004; pp. 266-269.

19. Saaty, T.L. Decision Making for Leaders: The Analytic Hierarchy Process for Decisions in a Complex World; RWS Publications: Pittsburgh, PA, USA, 1999.

20. Dos Santos, P.H.; Neves, S.M.; Sant'Anna, D.O.; de Oliveira, C.H.; Carvalho, H.D. The analytic hierarchy process supporting decision making for sustainable development: An overview of applications. J. Clean. Prod. 2019, 212, 119-138. [CrossRef]

21. Ahmad, S.; Tahar, R.M. Selection of renewable energy sources for sustainable development of electricity generation system using analytic hierarchy process: A case of Malaysia. Renew. Energy 2014. [CrossRef]

22. Saaty, T.L. Axiomatic Foundation of the Analytic Hierarchy Process. Manage. Sci. 1986, 32, 841-855. [CrossRef]

23. Ossadnik, W.; Schinke, S.; Kaspar, R.H. Group Aggregation Techniques for Analytic Hierarchy Process and Analytic Network Process: A Comparative Analysis. Gr. Decis. Negot. 2016, 25, 421-457. [CrossRef]

24. R Core Team. R: A Language and Environment for Statistical Computing; The R Project: Vienna, Austria, 2018.

25. Cho, F. Ahpsurvey: Analytic Hierarchy Process for Survey Data; The R Project: Vienna, Austria, 2019.

26. Lund, P.D.; Lindgren, J.; Mikkola, J.; Salpakari, J. Review of energy system flexibility measures to enable high levels of variable renewable electricity. Renew. Sustain. Energy Rev. 2015, 45, 785-807. [CrossRef]

27. Lewandowska-Bernat, A.; Desideri, U. Opportunities of power-to-gas technology in different energy systems architectures. Appl. Energy 2018, 228, 57-67. [CrossRef]

28. Bokde, N.; Tranberg, B.; Andresen, G.B. A graphical approach to carbon-efficient spot market scheduling for Power-to-X applications. Energy Convers. Manag. 2020, 224, 113461. [CrossRef]

29. Huber, M.; Dimkova, D.; Hamacher, T. Integration of wind and solar power in Europe: Assessment of flexibility requirements. Energy 2014. [CrossRef]

30. Vandewalle, J.; Bruninx, K.; D'Haeseleer, W. Effects of large-scale power to gas conversion on the power, gas and carbon sectors and their interactions. Energy Convers. Manag. 2015. [CrossRef]

31. Helgeson, B.; Peter, J. The role of electricity in decarbonizing European road transport-Development and assessment of an integrated multi-sectoral model. Appl. Energy 2020, 262, 114365. [CrossRef]

32. Hansen, K.; Mathiesen, B.V.; Skov, I.R. Full energy system transition towards $100 \%$ renewable energy in Germany in 2050. Renew. Sustain. Energy Rev. 2019, 102, 1-13. [CrossRef]

33. de Vasconcelos, B.R.; Lavoie, J.M. Recent advances in power-to-X technology for the production of fuels and chemicals. Front. Chem. 2019, 7, 392. [CrossRef] [PubMed]

34. Hansson, J.; Månsson, S.; Brynolf, S.; Grahn, M. Alternative marine fuels: Prospects based on multi-criteria decision analysis involving Swedish stakeholders. Biomass Bioenergy 2019, 126, 159-173. [CrossRef]

35. Brynolf, S.; Taljegard, M.; Grahn, M.; Hansson, J. Electrofuels for the transport sector: A review of production costs. Renew. Sustain. Energy Rev. 2018, 81, 1887-1905. [CrossRef]

36. Energinet.dk. PtX $i$ Danmark før 2030_Potentiale for PtX $i$ Danmark på Kortere sigt $i$ et Systemperspektiv; Energinet.dk: Fredericia, Denmark, 2019.

37. Lund, H.; Mathiesen, B.V.; Thellufsen, J.Z.; Sorknæs, P.; Skov, I.R. IDAs Klimasvar: Transport- og Energiløsninger 2030; Ingeniørforeningen IDA: Copenhagen, Denmark, 2020.

38. Keipi, T.; Tolvanen, H.; Konttinen, J. Economic analysis of hydrogen production by methane thermal decomposition: Comparison to competing technologies. Energy Convers. Manag. 2018. [CrossRef]

39. Saba, S.M.; Müller, M.; Robinius, M.; Stolten, D. The investment costs of electrolysis-A comparison of cost studies from the past 30 years. Int. J. Hydrogen Energy 2018, 43, 1209-1223. [CrossRef]

40. Nikolaidis, P.; Poullikkas, A. A comparative overview of hydrogen production processes. Renew. Sustain. Energy Rev. 2017. [CrossRef]

41. Skov, I.S.; Mathiesen, B.V. Danish Roadmap for Large-Scale Implementation of Electrolysers; Aalborg University: Copenhagen, Danmark, 2017. 
42. Hauch, A.; Küngas, R.; Blennow, P.; Hansen, A.B.; Hansen, J.B.; Mathiesen, B.V.; Mogensen, M.B. Recent advances in solid oxide cell technology for electrolysis. Science 2020, 370, 6118. [CrossRef]

43. Chi, J.; Yu, H. Water electrolysis based on renewable energy for hydrogen production. Cuihua Xuebao/Chin. J. Catal. 2018, 39, 390-394. [CrossRef]

44. Buttler, A.; Spliethoff, H. Current status of water electrolysis for energy storage, grid balancing and sector coupling via power-togas and power-to-liquids: A review. Renew. Sustain. Energy Rev. 2018, 82, 2440-2454. [CrossRef]

45. Weitemeyer, S.; Kleinhans, D.; Vogt, T.; Agert, C. Integration of Renewable Energy Sources in future power systems: The role of storage. Renew. Energy 2015. [CrossRef]

46. European Commission. A Clean Planet for All. A European Long-Term Strategic Vision for a Prosperous, Modern, Competitive and Climate Neutral Economy; European Commission: Brussels, Belgium, 2018.

47. Scarlat, N.; Dallemand, J.F.; Monforti-Ferrario, F.; Nita, V. The role of biomass and bioenergy in a future bioeconomy: Policies and facts. Environ. Dev. 2015. [CrossRef]

48. Connolly, D.; Mathiesen, B.V.; Ridjan, I. A comparison between renewable transport fuels that can supplement or replace biofuels in a 100\% renewable energy system. Energy 2014, 73, 110-125. [CrossRef]

49. Drechsler, C.; Agar, D.W. Intensified integrated direct air capture-Power-to-gas process based on $\mathrm{H} 2 \mathrm{O}$ and $\mathrm{CO} 2$ from ambient air. Appl. Energy 2020, 273, 115076. [CrossRef]

50. Mathiesen, B.V.; Ridjan, I.; Connolly, D.; Nielsen, M.P.; Hendriksen, P.V.; Mogensen, M.B.; Jensen, S.H.; Ebbesen, S.D. Technology Data for High Temperature Solid Oxide Electrolyser Cells, Alkali and PEM Electrolysers; Department of Development and Planning, Aalborg University: Copenhagen, Denmark, 2013.

51. Stančin, H.; Mikulčić, H.; Wang, X.; Duić, N. A review on alternative fuels in future energy system. Renew. Sustain. Energy Rev. 2020, 128. [CrossRef]

52. Chiaramonti, D.; Goumas, T. Impacts on industrial-scale market deployment of advanced biofuels and recycled carbon fuels from the EU Renewable Energy Directive II. Appl. Energy 2019, 251, 113351. [CrossRef]

53. Wulf, C.; Linßen, J.; Zapp, P. Review of Power-to-Gas Projects in Europe. Energy Procedia 2018, 155, 367-378. [CrossRef]

54. Bailera, M.; Lisbona, P.; Romeo, L.M.; Espatolero, S. Power to Gas projects review: Lab, pilot and demo plants for storing renewable energy and CO2. Renew. Sustain. Energy Rev. 2017, 69, 292-312. [CrossRef]

55. Dansk Industry. Anbefalinger til en Dansk Strategi for Power-to-X; Dansk Industry: Copenhagen Danmark, 2020.

56. Ørsted. Decarbonising Society with Power-to A Path to Scaling Production and Uptake of Renewable Hydrogen and Sustainable E-Fuels; Ørsted: Fredericia, Denmark, 2020.

57. Ørsted. Ørsted and Partners Secure Funding for Renewable Hydrogen Project. Available online: https://orsted.com/en/media/ newsroom/news/2019/12/945369984118407 (accessed on 10 December 2020).

58. State of Green Denmark Funds New Power-to-X Flagship Projects. Available online: https://stateofgreen.com/en/partners/ state-of-green/news/denmark-funds-new-power-to-x-flagship-projects/ (accessed on 10 December 2020).

59. European Parliament. Directive (EU) 2018/2001 of the European Parliament and of the Council of 11 December 2018 on the Promotion of the Use of Energy from Renewable Sources; European Parliament: Bruxelles, Belgium, 2018.

60. Hamelin, L.; Borzęcka, M.; Kozak, M.; Pudełko, R. A spatial approach to bioeconomy: Quantifying the residual biomass potential in the EU-27. Renew. Sustain. Energy Rev. 2019, 100, 127-142. [CrossRef]

61. Hintermayer, M. A carbon price floor in the reformed EU ETS: Design matters! Energy Policy 2020, 147, 111905. [CrossRef]

62. Van de Graaf, T.; Overland, I.; Scholten, D.; Westphal, K. The new oil? The geopolitics and international governance of hydrogen. Energy Res. Soc. Sci. 2020, 70, 101667. [CrossRef] [PubMed]

63. Mac Dowell, N.; Fennell, P.S.; Shah, N.; Maitland, G.C. The role of $\mathrm{CO}_{2}$ capture and utilization in mitigating climate change. Nat. Clim. Chang. 2017, 7, 243-249. [CrossRef]

64. Searle, S.; Christensen, A. Decarbonization Potential of Electrofuels in the European Union; The International Council on Clean Transportation: Washington, DC, USA, 2018.

65. Koj, J.C.; Wulf, C.; Zapp, P. Environmental impacts of power-to-X systems-A review of technological and methodological choices in Life Cycle Assessments. Renew. Sustain. Energy Rev. 2019, 112, 865-879. [CrossRef]

66. Schmidt, P.; Batteiger, V.; Roth, A.; Weindorf, W.; Raksha, T. Power-to-Liquids as Renewable Fuel Option for Aviation: A Review. Chemie Ing. Tech. 2018, 90, 127-140. [CrossRef]

67. Hansson, J.; Brynolf, S.; Fridell, E.; Lehtveer, M. The Potential Role of Ammonia as Marine Fuel—Based on Energy Systems Modeling and Multi-Criteria Decision Analysis. Sustainability 2020, 12, 3265. [CrossRef]

68. ben Brahim, T.; Wiese, F.; Münster, M. Pathways to climate-neutral shipping: A Danish case study. Energy 2019, 188, 116009. [CrossRef] 